AMERICAN METEOROLOGICAL SOCIETY

FINANCIAL STATEMENTS

YEAR ENDED DECEMBER 3I, 2018 


\section{INDEPENDENT AUDITOR'S REPORT}

To the Executive Committee

American Meteorological Society

Boston, Massachusetts

\section{Report on the Financial Statements}

We have audited the accompanying financial statements of American Meteorological Society (the "Society") which comprise the statement of financial position as of December 31,2018, and the related statements of activities, functional expenses, and cash flows for the year then ended, and the related notes to the financial statements.

\section{Management's Responsibility for the Financial Statements}

Management is responsible for the preparation and fair presentation of these financial statements in accordance with accounting principles generally accepted in the United States of America; this includes the design, implementation, and maintenance of internal control relevant to the preparation and fair presentation of financial statements that are free from material misstatement, whether due to fraud or error.

\section{Auditor's Responsibility}

Our responsibility is to express an opinion on these financial statements based on our audit. We conducted our audit in accordance with auditing standards generally accepted in the United States of America. Those standards require that we plan and perform the audit to obtain reasonable assurance about whether the financial statements are free from material misstatement.

An audit involves performing procedures to obtain audit evidence about the amounts and disclosures in the financial statements. The procedures selected depend on the auditor's judgment, including the assessment of the risks of material misstatement of the financial statements, whether due to fraud or error. In making those risk assessments, the auditor considers internal control relevant to the Society's preparation and fair presentation of the financial statements in order to design audit procedures that are appropriate in the circumstances, but not for the purpose of expressing an opinion on the effectiveness of the Society's internal control. Accordingly, we express no such opinion. An audit also includes evaluating the appropriateness of accounting policies used and the reasonableness of significant accounting estimates made by management, as well as evaluating the overall presentation of the financial statements.

We believe that the audit evidence we have obtained is sufficient and appropriate to provide a basis for our audit opinion.

\section{Opinion}

In our opinion, the financial statements referred to above present fairly, in all material respects, the financial position of American Meteorological Society as of December 31,2018, and the changes in its net assets and its cash flows for the year then ended in accordance with accounting principles generally accepted in the United States of America.

\section{Tannesan \& Company, PC}

Wakefield, Massachusetts

September 6, 2019 


\section{$\underline{\text { ASSETS }}$}

\section{ASSETS:}

Cash and cash equivalents

$\$$

$2,468,625$

Accounts receivable

438,248

Pledges receivable, net

254,252

Investments

$5,897,980$

Inventories

51,351

Property and equipment, net

$9,987,969$

Prepaid expenses and other current assets

$1,430,088$

TOTAL ASSETS

$\$$

$20,528,513$

\section{LIABILITIES AND NET ASSETS}

\section{LIABILITIES:}

Long-term debt

$\$$

$4,018,055$

$1,026,852$

Accounts payable and accrued expenses

$5,821,636$

Deferred revenue

228,258

Charitable gift annuity liability

32,308

Fair value of interest rate swap agreement

53,869

Deferred rent

Commitments

\section{TOTAL LIABILITIES}

$11,180,978$

\section{NET ASSETS:}

Without donor restrictions

With donor restrictions

TOTAL NET ASSETS

$9,347,535$

TOTAL LIABILITIES AND NET ASSETS

$\$$

$20,528,513$




\section{SUPPORT AND REVENUE:}

Publications

Meetings and exhibits

Membership and communication

Other educational assistance

Federal financial assistance

Investment return, net

Contributions

Net assets released from restrictions

Rental income

Change in fair value of interest rate swap

Total support and revenue

\section{EXPENSES:}

Program services:

Publications

Education and policy programs

Meetings and exhibits

Membership and communication

Student programs

Supporting services:

Administrative and general

Development

Total expenses

INCREASE (DECREASE) IN NET ASSETS

NET ASSETS, BEGINNING OF YEAR

NET ASSETS, END OF YEAR

\begin{tabular}{|c|c|c|}
\hline $\begin{array}{c}\text { Without Donor } \\
\text { Restrictions }\end{array}$ & $\begin{array}{l}\text { With Donor } \\
\text { Restrictions }\end{array}$ & Total \\
\hline $7,638,176$ & $\$$ & $7,638,176$ \\
\hline $4,701,339$ & - & $4,701,339$ \\
\hline $1,999,314$ & - & $1,999,314$ \\
\hline $1,930,106$ & - & $1,930,106$ \\
\hline $1,004,040$ & - & $1,004,040$ \\
\hline$(174,898)$ & $(201,398)$ & $(376,296)$ \\
\hline 310,295 & 398,445 & 708,740 \\
\hline 141,345 & $(141,345)$ & - \\
\hline 36,971 & - & 36,971 \\
\hline 54,853 & - & 54,853 \\
\hline $17,641,541$ & 55,702 & $17,697,243$ \\
\hline
\end{tabular}

$7,016,037$

$3,127,902$

$3,468,546$

$2,944,503$

625,670

$1,905,764$

296,507
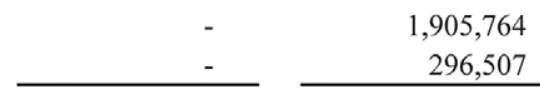

296,507

$19,384,929$

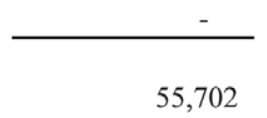

$19,384,929$

$(1,743,388)$

55,702

$(1,687,686)$

$7,732,252$

$3,302,969$

$11,035,221$

$\$$

$5,988,864$

$3,358,671$

$\$$

$9,347,535$ 
Payroll and related taxes

Conferences and meetings expense

Journal production and mailing

Employee benefits, health and welfare

Depreciation and amortization

Consulting

Employee benefits - retirement

Policy programs

Occupancy

Education programs and workshops

Education books production

Student scholarships and fellowships

Online hosting

Volunteer editor support

Bank charges and fees

Professional fees

Office supplies and expense

Computer expense

Student programs

Interest expense

Centennial expenses

Council and committee

Insurance

Repairs and maintenance

Affiliate membership dues

Utilities

Other membership expenses

Telephone

Book production and mailing

Commission support

Miscellaneous

Fundraising expenses other

Postage

Travel

Merchandise for resale

\section{Education and \\ Policy \\ Programs}

$\$$

$2,770,614 \$$

$1,219,776$

$1,869,939$

383,644

115,430

159,117

228,071

162,730

$-$

$-$

$-$

277,922

270,900

128,408

99,765

87,974

69,889

112,552

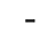

43,046

36,926

30,631

-

27,307

62,119

52,677

18,177

-

8,199
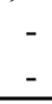

$\$$

$7,016,037$
$\$$

582,024

Meetings and Exhibits

$2,458,682$

168,901

47,147

229,102

100,409

404,182

66,467

361,838

357,750
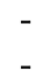

80,592

27,638

33,082

47,911

38,964
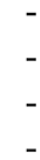

78,887

23,887

21,064

35,933

-

16,734

19,746

-

10,307

17,582

8,841

15,082

-

7,334

12,511

-

6,538

11,154

-

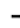

4,352

7,424

-

1,963

3,349

-

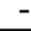
$\$ \frac{3,127,902}{=\$}$ $3,468,546$ 


\begin{tabular}{|c|c|c|c|c|c|c|c|c|c|}
\hline & $\begin{array}{l}\text { Membership and } \\
\text { Communication }\end{array}$ & & $\begin{array}{c}\text { Student } \\
\text { Programs }\end{array}$ & & $\begin{array}{c}\text { Administrative } \\
\text { and General }\end{array}$ & & Development & & Total \\
\hline \multirow[t]{35}{*}{$\$$} & $1,140,052$ & $\$$ & 77,534 & $\$$ & $1,041,419$ & $\$$ & 113,907 & $\$$ & $6,945,326$ \\
\hline & - & & - & & - & & - & & $2,458,682$ \\
\hline & 500,324 & & - & & - & & - & & $2,370,263$ \\
\hline & 157,862 & & 10,736 & & 144,205 & & 15,773 & & 961,713 \\
\hline & 519,989 & & 2,634 & & 30,891 & & 3,869 & & 747,598 \\
\hline & 90,451 & & 2,967 & & 34,802 & & 90,760 & & 640,281 \\
\hline & 93,847 & & 6,382 & & 85,728 & & 9,377 & & 571,725 \\
\hline & - & & - & & - & & - & & 404,182 \\
\hline & 66,467 & & 3,713 & & 43,547 & & 5,455 & & 387,343 \\
\hline & - & & - & & - & & - & & 361,838 \\
\hline & - & & - & & - & & - & & 357,750 \\
\hline & - & & 329,164 & & - & & - & & 329,164 \\
\hline & - & & - & & - & & - & & 277,922 \\
\hline & - & & - & & - & & - & & 270,900 \\
\hline & 33,548 & & - & & 26,733 & & - & & 267,576 \\
\hline & - & & - & & 253,900 & & - & & 253,900 \\
\hline & 40,749 & & 2,276 & & 26,696 & & 3,345 & & 237,467 \\
\hline & 35,933 & & 2,007 & & 23,543 & & 2,949 & & 209,403 \\
\hline & - & & 182,913 & & - & & - & & 182,913 \\
\hline & 28,546 & & 1,595 & & 18,703 & & 2,342 & & 166,355 \\
\hline & 19,746 & & - & & - & & - & & 152,044 \\
\hline & - & & - & & 116,725 & & - & & 116,725 \\
\hline & 17,582 & & 982 & & 11,520 & & 1,443 & & 102,462 \\
\hline & 15,082 & & 843 & & 9,883 & & 1,237 & & 87,894 \\
\hline & 77,250 & & - & & - & & - & & 77,250 \\
\hline & 12,511 & & 699 & & 8,197 & & 1,027 & & 72,910 \\
\hline & 68,507 & & - & & - & & - & & 68,507 \\
\hline & 11,154 & & 623 & & 7,308 & & 915 & & 64,999 \\
\hline & - & & - & & - & & - & & 62,119 \\
\hline & - & & - & & - & & - & & 52,677 \\
\hline & 7,424 & & 415 & & 4,865 & & 609 & & 43,266 \\
\hline & - & & - & & - & & 43,224 & & 43,224 \\
\hline & 3,349 & & 187 & & 2,194 & & 275 & & 19,516 \\
\hline & - & & - & & 14,905 & & - & & 14,905 \\
\hline & 4,130 & & - & & - & & - & & 4,130 \\
\hline$\$$ & $2,944,503$ & $\$$ & 625,670 & $\$$ & $1,905,764$ & $\$$ & 296,507 & $\$$ & $19,384,929$ \\
\hline
\end{tabular}


CASH FLOWS FROM OPERATING ACTIVITIES:

Cash received from publications

Cash received from education and policy programs

$2,063,057$

Cash received from meetings and exhibits

$4,492,617$

Cash received from membership and communication

$1,213,657$

173,886

Interest and dividends received

36,971

Cash received from contributions

Cash payments for salaries, benefits, and payroll taxes

Cash payments to vendors

Interest paid

Net cash used in operating activities

$(1,261,025)$

CASH FLOWS FROM INVESTING ACTIVITIES:

Purchase of property and equipment

$(194,694)$

Proceeds from sale of investments

$2,224,625$

Purchase of investments

$(1,506,305)$

Net cash provided by investing activities

523,626

\section{CASH FLOWS FROM FINANCING ACTIVITIES:}

Proceeds from long-term debt

500,000

Payments on long-term debt

$(683,333)$

Contributions restricted for endowment

202,463

Payments to charitable gift annuitants

Net cash used in financing activities

$(2,995)$

$(740,394)$

NET DECREASE IN CASH

$3,209,019$

CASH AND CASH EQUIVALENTS, BEGINNING OF YEAR

CASH AND CASH EQUIVALENTS, END OF YEAR

$\$$

$2,468,625$ 


\section{Note 1 - Summary of Significant Accounting Policies}

Nature of Activities-American Meteorological Society was formed in 1919. Interdisciplinary in scope, the Society actively promotes the development and dissemination of information on the atmospheric and related oceanic and hydrologic sciences.

Basis of Accounting-The financial statements of the Society have been prepared on the accrual basis of accounting in accordance with accounting principles generally accepted in the United States of America (U.S. GAAP).

Basis of Presentation-Under U.S. GAAP, the Society is required to report information regarding its financial position and activities according to the following net asset classifications:

Net assets without donor restrictions: Net assets that are not subject to donor-imposed restrictions and may be expended for any purpose in performing the primary objectives of the Society. These assets may be used at the discretion of the Society's management and board of directors.

Net assets with donor restrictions: Net assets subject to stipulations imposed by donors, and grantors. Some donor restrictions are temporary in nature; those restrictions will be met by action of the Society or by the passage of time. Other donor restrictions are perpetual in nature, where by the donor has stipulated the funds be maintained in perpetuity.

Estimates-The preparation of financial statements in conformity with U.S. GAAP requires management to make estimates and assumptions that affect the reported amounts of assets and liabilities and disclosure of contingent assets and liabilities at the date of the financial statements and the reported amounts of revenues and expenses during the reporting period. Actual results could differ from those estimates.

Cash and Cash Equivalents-Cash and cash equivalents consist of highly liquid investments with original maturities of ninety days or less. Cash equivalents are carried at cost which approximates fair value.
Note 1-Summary of Significant Accounting Policies (Continued)

Accounts Receivable-Accounts receivable are stated at the amount the Society's management expects to collect from outstanding balances. Management provides for probable uncollectible amounts through a charge to earnings and a credit to a valuation allowance based on historical collection experience, its assessment of current economic conditions, review and assessment of estimated funding sources, and the financial condition of the debtor. Balances which are still outstanding after the Society's management has used reasonable collection efforts are written off through a charge to the valuation allowance and a credit to accounts receivable. Accounts receivable have been reviewed by management and it has been determined that there is no requirement for an allowance for doubtful accounts as of December 31, 2018.

Pledges Receivable-Contributions, including unconditional promises to give, are recognized as revenues in the period received. Conditional promises to give are not recognized until they become unconditional; that is, when the conditions on which they depend are substantially met. Contributions of assets other than cash are recorded at their estimated fair value. Management provides for probable uncollectible amounts through a charge to earnings and a credit to a valuation allowance based on its assessment of the current status of individual accounts. Balances that are still outstanding after management has used reasonable collection efforts are written off through a charge to the valuation allowance and a credit to pledges receivable. Pledges receivable have been reviewed by management and it has been determined that there is no requirement for an allowance for doubtful accounts as of December 31, 2018. 


\section{Note 1-Summary of Significant Accounting Policies (Continued)}

Investments-The Society invests in marketable securities with readily determinable fair values and all investments in debt securities are reported at their fair values in the Statement of Financial Position. Unrealized gains and losses are included in the change in net assets in the accompanying Statement of Activities. Gains and losses on the disposition of investments are accounted for on the average cost method for equities and specific identification method for other securities. Investment income and gains restricted by donors are reported as increases in net assets with donor restrictions. When a restriction expires (that is, when a stipulated time restriction ends, or purpose restriction is accomplished), net assets with donor restrictions are reclassified to net assets without donor restrictions and reported in the Statement of Activities as net assets released from restriction.

The Society maintains a master investment account for its donor-restricted endowments, unless specified to be segregated by the donor. Realized and unrealized gain and losses from securities in the master account are allocated monthly to the individual endowments based on the relationship of the market value of each endowment to the total market value of the master investment account, as adjusted for additions to or deductions from those accounts.

The Society maintains an investment portfolio consisting of a combination of long-term cash and cash equivalents, fixed income, common stocks, and equity securities. Investment securities are exposed to various risks, such as interest rate, market and credit risks. Due to the level of risk associated with certain investments, it is at least reasonably possible that changes in the value of these investments will occur in the near term and such changes could materially affect the Society's investment account balances.

Inventories-Inventories, consisting primarily of periodicals and books, are stated at net realizable value.

\section{Note 1-Summary of Significant Accounting Policies (Continued)}

Property and Equipment-Property and equipment are carried at cost or, if donated, at the approximate fair value at the date of donation. Depreciation is computed using primarily the straight-line method over the estimated useful lives of the assets which range from three to forty years. Additions and betterments of $\$ 2,000$ or more are capitalized, while maintenance and repairs that do not improve or extend the useful lives of the respective assets are expensed.

The Society's land and buildings are located in a historical district and its original building is classified as a historical structure. The original property is considered to be a historical treasure that is worth preserving perpetually. The Society has the capacity to protect and preserve essentially the service potential of the land and building and is doing so.

Derivative Financial Instruments-The Society makes use of derivative financial instruments for the purpose of managing interest rate risk. Derivative financial instruments are recorded at fair value. Interest rate swap agreements are valued at the net present value of future cash flows attributable to the difference between the contractual variable and fixed rates in those agreements adjusted for nonperformance risk of both the counterparty and the Society.

Revenue Recognition-All revenue from publications, meetings and exhibits, membership and communication and other educational assistance are recognized in the year in which the publication is issued, the meeting or event has taken place, or the services are performed. Payments received in advance are reflected as deferred revenue until the meeting or event has taken place or service has been performed. 


\section{Note 1-Summary of Significant Accounting Policies (Continued)}

Contributed Services-Contributed services are recognized as contributions if the services create or enhance non-financial assets or require specialized skills, are performed by people with those skills, and would otherwise be purchased by the Society. Contributed services are recognized as revenue at the estimated fair value when the service is received. Donated legal services valued at approximately $\$ 60,000$ are included in the accompanying Statement of Activities. In addition, many individuals volunteer their time and perform a variety of tasks that assist the Society with various programs and committee assignments, but these services do not meet the criteria for recognition as contributed services.

Functional Allocation of Expenses-The financial statements report certain categories of expenses that are attributed to more than one program or supporting function. Therefore, expenses require allocation on a reasonable basis that is consistently applied. The expenses that are allocated include occupancy costs, utilities, office expenses and depreciation based on the average number of full-time equivalent employees during the year. Other expenses are allocated based on time and effort.

The following program and supporting services are included in the accompanying financial statements:

\section{Publications}

Includes the publication of the Society's primary journals (Journal of the Atmospheric Sciences, Journal of Applied Meteorology and Climatology, Monthly Weather Review, Journal of Physical Oceanography, Journal of Atmospheric and Oceanic Technology, Journal of Climate, Weather and Forecasting, Weather, Climate and Society, Journal of Hydrometeorology and Earth Interactions electronic journal).
Note 1-Summary of Significant Accounting Policies (Continued)

\section{Functional allocation of expenses (Continued)}

\section{Education and Policy Programs}

Includes federal funding and Society support of nationally recognized programs using the study of the atmosphere and ocean to enhance or create an interest in pre-college students in science and engineering. Programs include, among others, AMS/NOAA Cooperative Program for Earth System Education, AMS Summer Policy Colloquium 2018-2020, AMS Climate Studies and Research Opportunities in Space and Earth Sciences. Policy programs work to strengthen the connection between public policy and Earth system science and services by building policy research and by creating opportunities for policymakers and scientists to engage and exchange perspectives to foster better-informed policy decisions. In addition, this includes the production and sale of books published by the Society, distribution throughout North America of WMO publications and sale of educational material for pre-college teachers.

\section{Meetings and Exhibits}

Includes presenting various meetings throughout the year including the annual meeting and the related exhibits. It also includes short courses offered at the various meetings.

\section{Membership and Communication}

Includes all primary member services, including, among others, the maintenance of the membership database, the certification programs and the publication of the Bulletin.

\section{Student Programs}

Includes the granting and administration of the many undergraduate scholarships and graduate fellowships offered by the Society, and support for other student programs, such as student travel grants to scientific conferences and the annual AMS Student Conference. 


\author{
Note 1-Summary of Significant Accounting Policies \\ (Continued)
}

Functional allocation of expenses (Continued)

\section{Administrative and General}

Includes the functions necessary to maintain a portion of an equitable employment program; ensure an adequate working environment; provide coordination and articulation of the Society's program strategy through the Office of the Executive Director; secure proper administrative functioning of the Council; maintain competent legal services for the program administration of the Society; and manage the financial and budgetary responsibilities of the Society.

\section{Development}

Includes conducting special fundraising events; and other activities involved with soliciting contributions from corporations, foundations, individuals and others.

Advertising-The Society uses advertising to promote its programs, bulletins, journals, books and education materials among the audiences it serves. The production costs of advertising are expensed as incurred.

Income Tax Status-The Society is exempt from federal income tax under Section 501(c)(3) of the Internal Revenue Code. However, income from certain activities not directly related to the Society's tax-exempt purpose is subject to taxation as unrelated business income. The Society had no material unrelated business income for the year ended December 31, 2018.

In determining the recognition of uncertain tax positions, the Society applies a more-likely-than-not recognition threshold and determines the measurement of uncertain tax positions considering the amounts and probabilities of the outcomes that could be realized upon ultimate settlement with taxing authorities. As of December 31, 2018, the Society has no uncertain tax positions that qualify for either recognition or disclosure in the financial statements. The Society is not currently under examination by any taxing jurisdiction. The Society's federal and state tax returns are generally open for examination for three years following the date filed.

\section{Note 1-Summary of Significant Accounting Policies (Continued)}

Concentration of Credit Risk-The Society places its cash in institutions which are insured by the Federal Deposit Insurance Corporation (FDIC). At times during the year, the bank balances may be in excess of the FDIC insurance limit of $\$ 250,000$ per institution. At December 31, 2018, the Society's bank balances exceeded the FDIC limit by approximately $\$ 3,050,000$.

The Society also holds various investment funds in a combination of long-term cash and cash equivalents, fixed income, equity securities, and common stocks. At December 31, 2018, the Society had $\$ 5,897,980$ in brokerage accounts, which were not insured and subject to various risks, such as interest rate, market and credit risks.

Subsequent Events-The date to which events occurring after December 31, 2018 have been evaluated for possible adjustment to the financial statements or disclosure is the date of the Independent Auditor's Report which is the date the financial statements were available to be issued. 


\section{Note 1-Summary of Significant Accounting Policies (Continued)}

Recent Accounting Pronouncements-During August 2016, The Financial Accounting Standards Board issued Accounting Standards Update (ASU) 2016-14, Presentation of Financial Statements of Not-for-Profit Entities. The Standard simplifies and improves how not-for-profit entities classify net assets as well as the information presented in the financial statements and notes about liquidity, financial performance, and cash flows. The Standard (1) revises the net asset classification scheme to two classes instead of the previous three, (2) enhances disclosures for self-imposed limits on the use of resources without donor-imposed restrictions and the composition of net assets with donor restrictions, (3) updates the accounting and disclosure requirements for underwater endowment funds, (4) requires the net presentation of investment expenses against investment return on the statement of activities and eliminates the requirement to disclose investment expenses that have been netted, (5) requires the presentation of expenses by nature as well as function, (6) requires qualitative disclosures on how a not-for-profit manages its available liquid resources, (7) requires quantitative disclosures that communicate the availability of financial assets to meet cash needs for general expenditures within one year of the statement of financial position date, and (8) allows for a choice between the direct and indirect method of reporting operating cash flows. During the year ended December 31, 2018, the Society adopted ASU 2016-14 and has adjusted the presentation of the financial statements accordingly. The ASU has been applied retrospectively to all periods presented.

The Financial Accounting Standards Board has issued ASU 2014-09, Revenue from Contracts with Customers. The Standard's core principle is that a company will recognize revenue when it transfers promised goods or services to customers in an amount that reflects the consideration to which the company expects to be entitled in exchange for the goods or services. This Standard also includes expanded disclosure requirements that result in an entity providing users of financial statements with comprehensive information about the nature, amount, timing, and uncertainty of revenue and cash flows arising from the entity's contracts with customers. This Standard will be effective for the year ending December 31,2019 . The Society is currently in the process of evaluating the impact of this ASU on the financial statements.

\section{Note 1-Summary of Significant Accounting Policies (Continued)}

The Financial Accounting Standards Board has issued ASU 2016-02, Leases. The Standard requires all leases with lease terms over 12 months to be capitalized as a right-of-use asset and lease liability on the statement of financial position at the date of lease commencement. Leases will be classified as either finance or operating. This distinction will be relevant for the pattern of expense recognition in the statement of activities. This Standard will be effective for the year ending December 31,2020. The Society is currently in the process of evaluating the impact of the adoption of this ASU on the financial statements.

\section{Note 2-Availability and Liquidity}

The Society strives to maintain liquid financial assets sufficient to cover 90 days of general expenditures (approximately $\$ 4,600,000)$. Financial assets in excess of daily cash requirements are invested in certificates of deposit, money market funds and other short-term investments. The Society also has a $\$ 500,000$ line of credit to meet cash flow needs.

In addition, the Society receives contributions with donor restrictions to be used in accordance with the associated purpose restrictions. It also receives gifts to establish endowments that will exist in perpetuity; the income generated from such endowments is used to fund programs. The Society also receives support without donor restrictions.

The Society considers investment income without donor restrictions, appropriated earnings from donorrestricted endowments, contributions without donor restrictions and contributions with donor restrictions for use in current programs which are ongoing, major, and central to its annual operations to be available to meet cash needs for general expenditures. General expenditures include administrative and general expenses and fundraising expenses expected to be paid in the subsequent year. Annual operations are defined as activities occurring during the Society's fiscal year. 


\section{Note 2-Availability and Liquidity (Continued)}

The Society manages its cash available to meet general expenditures following three guiding principles:

- Operating within a prudent range of financial soundness and stability,

- Maintaining adequate liquid assets, and

- Maintaining sufficient reserves to provide reasonable assurance that long term grant commitments and obligations under endowments with donor restrictions and quasi-endowments that support mission fulfillment will continue to be met, ensuring the sustainability of the Society.

The table below presents financial assets available for general expenditures within one year at December 31, 2018:

Financial assets at year-end:

Cash and cash equivalents

$\$ 2,468,625$

Accounts receivables

438,248

Pledges receivable

254,252

Investments

Total financial assets

$5,897,980$

$9,059,105$

Less amounts not available to be used within one year:

Collateral under security lending agreements

500,000

Pledges receivable due after one year, net

94,380

Investments held as endowments

881,370

Financial assets not available to be used within one year

$1,475,750$

Financial assets available to meet general expenditures

$7,583,355$

within one year

Liquidity resources - Line of credit borrowings

500,000

Total financial assets and liquidity resources available to meet general expenditures within one year

$\$$ $8,083,355$

\section{Note 3-Pledges Receivable}

At December 31, 2018, pledges receivable consist of the following:

Pledges expected to be collected in:

Less than one year

One to five years

98,000

More than five years

Less present value discount $(23,620)$

Pledges receivable, net

\begin{tabular}{lr} 
& $(23,620)$ \\
\hline$\$ \quad 254,252$ \\
\hline \hline
\end{tabular}




\section{Note 4-Investments}

The cost and fair value of investments at December 31, 2018 were as follows:

Equities

Cash and cash equivalents

Fixed income

Common stock

\begin{tabular}{|c|c|c|c|}
\hline \multicolumn{2}{|c|}{ Cost } & \multicolumn{2}{|c|}{ Fair Value } \\
\hline$\$$ & $4,643,707$ & $\$$ & $4,858,533$ \\
\hline & 296,606 & & 296,944 \\
\hline & 750,736 & & 722,954 \\
\hline & - & & 19,549 \\
\hline$\$$ & $5,691,049$ & $\$$ & $5,897,980$ \\
\hline
\end{tabular}

\section{Note 4-Investments (Continued)}

would be received to sell an asset, or paid to transfer a liability, in orderly transactions between market participants. Further, the Society is required to maximize the use of observable market inputs, minimize the use of unobservable market inputs, and disclose in the form of an outlined hierarchy the details of such fair value measurements. The hierarchy of valuation techniques is based on whether inputs to a fair value measurement are considered to be observable or unobservable in a marketplace. Observable inputs reflect market data obtained from independent sources, while unobservable inputs reflect the Society's market assumptions.

This hierarchy requires the use of observable market data when available. These inputs have created the following fair value hierarchy:

- Level 1-quoted prices in active markets that are unadjusted and accessible at the measurement date for identical unrestricted assets or liabilities. The fair value hierarchy gives the highest priority to Level 1 inputs;

- Level 2-quoted prices for identical assets and liabilities in markets that are not active, quoted prices for similar assets and liabilities in active markets or financial instruments for which significant inputs are observable, either directly or indirectly; and

- Level 3-prices or valuations that require inputs that are both significant to the fair value measurement and unobservable. The fair value hierarchy gives the lowest priority to Level 3 inputs.
The asset's fair value measurement level with the fair value hierarchy is based on the lowest level of any input that is significant to the fair value measurement. Valuation techniques used need to maximize the use of observable inputs and minimize the use of unobservable inputs. The guidance requires the use of observable data if such data is available without undue cost and effort.

Following is a description of the Society's valuation methodologies for assets measured at fair value.

Cash and cash equivalents: These investments are valued at the daily closing price as reported by the investment broker. Investments in long-term cash and cash equivalents are classified as Level 1 of the valuation hierarchy.

Equities: These investments are public investment vehicles valued using the Net Asset Value ("NAV") provided by the administrator of the fund and calculated at the close of business on various stock exchanges. The NAV is based on the value of the underlying asset owned by the fund, minus its liabilities, and then divided by the number of shares outstanding. Investments in equities are classified as Level 1 of the valuation hierarchy.

Fixed income: These investments are valued at the closing price of the active market in which the individual securities are traded. Investments in fixed income securities are classified as Level 1 of the valuation hierarchy. 


\section{Note 4-Investments (Continued)}

Common stock: These investments are valued at the closing price reported on the active market on which the individual securities are traded. Investments in common stock are classified as Level 1 of the valuation hierarchy.

\section{Note 4-Investments (Continued)}

Although the Society believes its valuation methodologies are appropriate and consistent with other market participants, the use of different methodologies or assumptions to determine the fair value of certain financial instruments could result in a different fair value measurement at the reporting date.

The following table summarizes by level, within the fair value hierarchy, the Society's financial assets measured at fair value on a recurring basis in accordance with U.S. GAAP as of December 31,2018:

Cash and cash equivalents

Equities:

Foreign large blend

Large blend

Small blend

Real estate

Foreign large growth

Financial services

Large growth

Mid-cap blend

Health

Technology

Diversified emerging markets

Industries

Intermediate-term bond

Inflation protected bond

Short-term bond

Industrials

Consumer defensive

Pacific/Asia ex-Japan Stk

Energy

Market neutral

Option writing

Consumer cyclical

Nontraditional bond

Large value

Basic materials

Mid-cap growth

Communication services

Fixed income:

Intermediate-term bond

Inflation protected bond

Bank loan

Short-term bond

World bond

Common stock-insurance
Level 1

$\begin{array}{r}296,944 \\ 502,239 \\ 474,999 \\ 391,470 \\ 324,086 \\ 273,358 \\ 262,430 \\ 246,317 \\ 244,067 \\ 221,247 \\ 218,405 \\ 212,511 \\ 211,440 \\ 155,694 \\ 150,344 \\ 145,315 \\ 141,613 \\ 101,429 \\ 89,999 \\ 86,688 \\ 83,412 \\ 81,529 \\ 54,753 \\ 49,775 \\ 47,306 \\ 41,966 \\ 26,464 \\ 19,677 \\ 440,566 \\ 132,716 \\ 90,670 \\ 39,443 \\ 19,559 \\ 19,549 \\ \hline 5,897,980 \\ \hline \hline\end{array}$




\section{Note 5-Property and Equipment}

Property and equipment consist of the following at December 31, 2018:

Buildings and improvements

Land and land improvements

Software

Office equipment and furniture

Less: accumulated depreciation

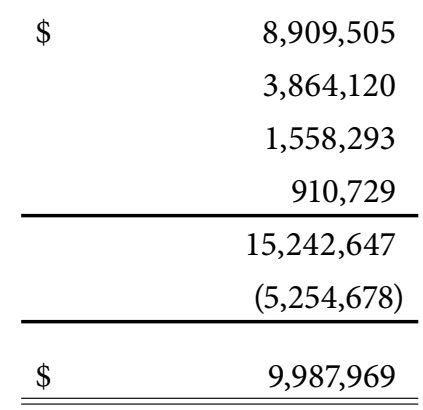

Note 7-Long-Term Debt

The Society entered into a loan agreement with the Massachusetts Development Finance Agency, (the "Issuer"), a public instrumentality of the Commonwealth of Massachusetts in 2010. The note was issued with bonds, by and among the Issuer, the Society, Webster Massachusetts Security Corporation, (the "Bondholder"), and Webster Bank National Association (the "Bank"). The note is payable in monthly installments of $\$ 15,278$ plus interest through November 2040. The interest rate on the note is set by the Bank and will be reset from time to time. At December 31, 2018, the interest rate was $3.17626 \%$. Interest expense for the year ended December 31, 2018 totaled $\$ 166,355$. The bond is secured by the land and building located at 44 Beacon Street, Boston, Massachusetts with a net book value of $\$ 6,829,466$ at December 31, 2018 . The note is subject to the same covenants, security and cross collateralization as the line of credit. (Reference is made to Note 6.)

Maturities of long-term debt at December 31, 2018 consist of the following:

\begin{tabular}{crr} 
Years & \multicolumn{1}{c}{ Amount } \\
\cline { 1 - 1 } 2019 & & 183,333 \\
2020 & & 183,333 \\
2021 & & 183,333 \\
2022 & & 183,333 \\
2023 & & 183,333 \\
Thereafter & $3,101,390$ \\
& & $4,018,055$ \\
\cline { 2 - 3 } & &
\end{tabular}




\section{Note 8-Interest Rate Swap Agreement}

The Society has an interest rate swap to mitigate the risk of changes in interest rates associated with its variable interest rate indebtedness. At December 31, 2018, the aggregate notional amount totaled $\$ 4,018,055$. The Society's agreement effectively changes the interest rate exposure on its bond payable to a fixed rate of $3.7075 \%$. The interest rate swap agreement matures in November 2020. U.S. GAAP requires the Society to recognize a gain or loss on the change in the fair market value of the swap agreement. The Society recognized a gain totaling $\$ 54,853$ on the change in the fair value of the swap agreement during the year ended December 31, 2018.

The fair value of the swap agreement is estimated as the present value of expected future cash inflows, taking into account (1) the type of security, its terms, and any underlying collateral, (2) the seniority level of the debt security, and (3) quotes received from brokers and pricing services. The interest rate swap agreement is measured at fair value on a recurring basis and is classified as Level 2 of the valuation hierarchy. At December 31, 2018 the interest rate swap liability amounted to $\$ 32,308$.

\section{Note 9-Split Interest Agreements}

The Society administers various charitable gift annuities. A charitable gift annuity provides for the payment of distributions to the grantor or other designated beneficiaries over the trust term (usually the designated beneficiary's lifetime). The portion of the gift annuity attributable to the present value of the future benefits to be received by the Society is recorded in the Statement of Activities as a contribution with donor restrictions in the period the gift annuity is established. Assets held in the various charitable gift annuities totaled approximately $\$ 276,000$ at December 31, 2018 and are recorded at fair value in the Society's Statement of Financial Position.

On an annual basis, the Society revalues the liability to make distributions to the designated beneficiaries based on actuarial assumptions. The present value of the estimated future payments totals approximately $\$ 228,000$ at December 31, 2018 and is calculated using discount rates ranging between $4.7 \%$ and $7.2 \%$ and applicable mortality tables.

\section{Note 10-Compensated Absences}

It is the Society's policy to reasonably estimate each year the amount of accrued vacation compensation that it anticipates to pay in the future. As of December 31, 2018, the Society has an accrued liability of approximately $\$ 508,000$ related to this policy, which is included in accounts payable and accrued expenses in the Statement of Financial Position.

\section{Note 11-Retirement Plan}

The Society has a contributory retirement plan covering substantially all full-time employees. This is a tax deferred annuity plan under Section 403(b) of the U.S. Internal Revenue Code. The plan allows eligible employees to contribute up to $100 \%$ of eligible compensation through a salary reduction agreement, up to the maximum permitted by the Internal Revenue Code.

The Society contributes $10 \%$ of eligible compensation for participating employees who contribute at least 5\% of eligible compensation. The expense for this plan amounted to $\$ 570,142$ for the year ended December 31, 2018.

While the Society expects to continue the plan indefinitely, the Society has reserved the right to modify, amend or terminate the plan. In the event of termination, the entire amount contributed under the plan must be applied to the payment of benefits to the participants or their beneficiaries.

\section{Note 12-Commitments}

The Society leases office space and equipment under various operating leases through March 2027. Under the terms of the office space lease, the Society is obligated to pay escalation rental for certain operating expenses and real estate taxes. Escalating rents are recognized on a straight-line basis over the term of the lease in accordance with U.S. GAAP. Rental expense under the leases totaled approximately $\$ 387,000$ for the year ended December 31, 2018 (including charges for operating expenses and taxes). 


\section{Note 12-Commitments}

The following is a schedule of the approximate future minimum rentals under the leases at December 31, 2018:

\begin{tabular}{crr} 
Years & \multicolumn{1}{c}{ Amount } \\
\cline { 1 - 1 } 2019 & & 390,000 \\
2020 & & 330,000 \\
2021 & 340,000 \\
2022 & & 350,000 \\
2023 & & 350,000 \\
Thereafter & & $1,210,000$ \\
& & \\
\cline { 2 - 3 } & &
\end{tabular}

\section{Note 13-Endowment Funds}

The Society's endowment consists of various individual funds established for a variety of purposes. Its endowment includes only donor-restricted endowment funds. As required by generally accepted accounting principles, net assets associated with endowment funds including funds designated by the Executive Committee to function as endowments, are classified and reported based on the existence or absence of donor-imposed restrictions. When the donor's interest is not expressed in relation to the endowment fund, it is the policy of the Society to record the income, interest, and dividends and accumulated appreciation/depreciation in each endowment fund and appropriate expenditures from each fund in a prudent manner for the uses, benefits, purpose, and duration for which the endowment fund was established. As a result, the income earned each year for each endowment fund is reflected as income with donor restrictions until appropriated for use.

\section{Note 13-Endowment Funds (Continued)}

Interpretation of Relevant Law: The Society is subject to the Massachusetts Uniform Prudent Management of Institutional Funds Act (MA UPMIFA) and, thus, classifies amounts in its donor-restricted endowment funds as net assets with donor restrictions as though net assets are time restricted until the Executive Committee appropriates such amounts for expenditure. Most of these net assets are also subject to purpose restrictions that must be met before reclassifying those net assets to assets without donor restrictions. The Executive Committee of the Society has interpreted MA UPMIFA as requiring the maintenance of purchasing power of the original gift amount contributed to an endowment fund. As a result of this interpretation, when reviewing its donor-restricted endowment funds, the Society considers a fund to be underwater if the fair value of the fund is less than then sum of (a) the original value of the initial and subsequent gift amounts donated to the fund and (b) any accumulations to the fund that are required to be maintained in perpetuity in accordance with the direct of the applicable donor gift instrument. The Society has interpreted MA UPMIFA to permit spending from underwater funds in accordance with the prudent measures required under the law. Additionally, in accordance with MA UPMIFA, the Society considers the following factors in making a determination to appropriate or accumulate donor-restricted endowment funds:

1) The duration and preservation of the various funds.

2) The purposes of the Society and the donor-restricted endowment funds.

3) General economic conditions.

4) The possible effect of inflation and deflation.

5) The expected total return from income and the appreciation of investments.

6) Other resources of the Society.

7) The investment policies of the Society. 


\section{Note 13-Endowment Funds (Continued)}

Investments and spending policies: The Society has adopted investment and spending policies approved by the Executive Committee for endowment assets that attempt to provide a predictable stream of funding to programs supported by its endowment funds while also maintaining the purchasing power of those endowment assets. Endowment assets include those assets of donorrestricted funds that the Society must hold in perpetuity. Under this policy, as approved by the Executive Committee, the endowment assets are invested in a manner that is intended to contribute to the Society's total return objectives and preserve principal while maintaining a competitive yield as market conditions dictate.

To satisfy its long-term rate-of-return objectives, the Society relies on a total return strategy in which investment returns are achieved through both capital appreciation (realized and unrealized) and current yield (interest and dividends). The Society targets a diversified conservative asset allocation including equity and marketable debt securities to achieve its long-term return objectives within prudent risk constraints.

\section{Note 13-Endowment Funds (Continued)}

The Society's policy of appropriating for distributions of its endowment fund for scholarships, fellowships and other distribution of funds is determined based on the donor's intentions and investment returns as well as taking into consideration the long-term expected return on its endowment, the nature and duration of the individual endowment funds, and the possible effects of inflation. Accordingly, over the long-term, the Society expects the current spending policy to allow its endowment to grow at a normal inflationary rate on an annual basis. This is consistent with the Society's objective to maintain the purchasing power of the endowment assets held in perpetuity or for a specific term as well as to provide additional growth through new gifts and investment return.

Underwater endowment funds: From time to time, the fair value of assets associated with individual donor-restricted endowment funds may fall below the level that the donor or MA UPMIFA requires the Society to retain as a fund of perpetual duration. In accordance with U.S. GAAP, deficiencies of this nature are reported in net assets with donor restrictions. Deficiencies of this nature exist in four donor-restricted endowment funds, which together have an original gift value of $\$ 239,778$, a fair value of $\$ 222,514$ at December 31, 2018, and a deficiency of $\$ 17,264$ as of December 31, 2018. These deficiencies resulted from unfavorable market fluctuations that occurred in the last quarter of 2018.

The changes in endowment net assets for year ended December 31, 2018 are as follows:

\begin{tabular}{|c|c|c|c|c|c|c|}
\hline \multirow[b]{2}{*}{$\begin{array}{l}\text { Endowment net assets, } \\
\text { beginning of year }\end{array}$} & \multicolumn{2}{|c|}{$\begin{array}{c}\text { Without Donor } \\
\text { Restrictions }\end{array}$} & \multicolumn{2}{|c|}{$\begin{array}{l}\text { With Donor } \\
\text { Restrictions }\end{array}$} & \multicolumn{2}{|c|}{ Total } \\
\hline & $\$$ & - & $\$$ & $1,059,702$ & $\$$ & $1,059,702$ \\
\hline Investment return, net & & - & & $(82,602)$ & & $(82,602)$ \\
\hline Contributions & & - & & 202,463 & & 202,463 \\
\hline $\begin{array}{l}\text { Appropriation of } \\
\text { cumulative gains }\end{array}$ & & - & & $(39,460)$ & & $(39,460)$ \\
\hline $\begin{array}{l}\text { Endowment net assets, end } \\
\text { of year }\end{array}$ & $\$$ & - & $\$$ & $1,140,103$ & $\$$ & $1,140,103$ \\
\hline
\end{tabular}




\section{Note 14-Net Assets}

Net assets with donor restrictions are restricted for the following purposes at December 31, 2018:

Endowment Funds (including historical gift value of $\mathbf{\$ 8 8 3 , 2 7 2 )}$

\section{Specific Purpose}

Scholarship awards

$\$$

$1,123,454$

Student travel awards

1,000

Student paper awards

15,649

$1,140,103$

Other Donor Restricted Funds

Specific Purpose

Scholarship awards

Hydrology research

Remote sensing awards

108,324

Lecture series awards

Student travel awards

110,399

Student paper awards

Building repair

30,000

$1,742,137$

Passage of Time

Charitable gift annuities

275,970

Pledges receivable

200,461

476,431

$\$$

$3,358,671$

Net assets were released from donor restrictions by incurring expenses satisfying the restricted purposes or by the occurrence of the passage of time or other events specified by donors:

Purpose restrictions accomplished:

Scholarship awards

$\$$

62,281

Hydrology research

Remote sensing awards

Lecture series awards

Student travel awards

6,964

Student paper awards

Time restrictions expired:

22,124

Charitable gift annuities

Release of appropriated amounts with purpose restrictions:

Scholarship awards

47,146

Student paper awards 